\title{
ADJUDICATION AND ITS DISCONTENTS: COHERENCE AND CONCILIATION IN FEDERAL INDIAN LAW
}

\author{
Philip P. Frickey*
}

\begin{abstract}
Federal Indian law is rooted in conflicting principles that leave the field in a morass of doctrinal and normative incoherence. In this Commentary, Professor Frickey begins by criticizing two recent efforts to bring coherence to this field. One approach, which narrows the scope of inquiry and attempts to apply non-normative doctrinal analysis, ignores the fictional nature of much federal Indian law doctrine and fails to appreciate the significance of normative and historical principles lurking behind the doctrine. The other approach, which seeks to construct a single descriptive paradigm from the case law, fails because federal Indian law precedents do not lend themselves to a unified theory. Professor Frickey suggests that greater coherence and respect for basic normative principles are likely to result from conceiving of the field as involving the process of negotiation among sovereigns rather than of adjudication in federal court.
\end{abstract}

\section{INTRODUCTION: To TAME A CONCEPTUAL WILDERNESS}

If the "life of the law" for legal formalists is logic and for legal pragmatists is experience, ${ }^{1}$ then federal Indian law is for neither. More than any other field of public law, federal Indian law is characterized by doctrinal incoherence ${ }^{2}$ and doleful incidents. ${ }^{3}$ Its principles aggregate into competing clusters of inconsistent norms, ${ }^{4}$ and its practical effect has been to legitimate the colonization of this continent the displacement of its native peoples - by the descendants of Europeans. ${ }^{5}$

One side of this story emphasizes the linkage between law and deprivation. ${ }^{6}$ From this perspective, if there is any bedrock principle

* Faegre \& Benson Professor of Law, University of Minnesota. Stuart Benjamin, Reid Chambers, Jim Chen, Paul Frye, Nell Jessup Newton, Joseph William Singer, Charles Stringer, and Gerald Torres provided helpful comments on an earlier draft of this essay. I also thank Robert Mnookin for advice on issues concerning negotiation and Stuart Benjamin for sharing his manuscript with me.

1 Oliver Wendell holmes, JR., The Common LaW 5 (Mark deWolfe Howe ed., 1963) (I88I).

2 See, e.g., Joseph W. Singer, Remembering What Hurts Us Most: A Critique of The American Indian Law Deskbook, 24 N.M. L. REv. 315, 318 (I994).

3 See, e.g., Robert N. Clinton, Redressing the Legacy of Conquest: A Vision Quest for a Decolonized Federal Indian Law, 46 ARK. L. REV. 77, 77-85 (I993).

4 See, e.g., Philip P. Frickey, Congressional Intent, Practical Reasoning, and the Dynamic Nature of Federal Indian Law, 78 CAL. L. Rev. Ir37, Ir74 (1990).

5 See, e.g., Rennard Strickland, Genocide-at-Law: An Historic and Contemporary View of the Native American Experience, 34 KAN. L. REv. 713, 718-2I (1986); Robert A. Williams, Jr., The Algebra of Federal Indian Law: The Hard Trail of Decolonizing and Americanizing the White Man's Indian Jurisprudence, 1986 WIS. L. REV. 2 I9, 223-24.

6 See, e.g., Milner S. Ball, Constitution, Court, Indian Tribes, I987 AM. B. Found. REs. J. I, I-II; Williams, supra note 5 , at 219-99. 
in the field at all, it is that might makes right. A century and a half ago, Chief Justice Marshall seemingly acknowledged as much when he equated the "discovery" of the continent with the "conquest" of its lands and peoples. ${ }^{7}$ From this, Chief Justice Marshall concluded that this fictional "conquest" gives the colonizers legal rights "which the Courts of the conqueror cannot deny, whatever the private and speculative opinions of individuals may be, respecting the original justice of the claim which has been successfully asserted."

Inevitably, there has been another, more optimistic side to this story, which emphasizes tribal survival rather than legal doctrines. Even five centuries after first European contact, the colonization remains incomplete. More than 500 tribes are recognized by the federal government today. 9 They possess a variety of powers of self-government, including a police power over their members on tribal lands ${ }^{10}$ and some authority to regulate the conduct of nonmembers there. ${ }^{11}$ Although the resistance of native institutions to complete assimilation is surely the product of indigenous resolve rather than Euro-American beneficence, ${ }^{12}$ perhaps the federal courts deserve modest credit for sometimes tempering the roughest qualities of colonization, in bequeathing to us an ambiguous heritage of "a conqueror with a conscience."13

These two competing narratives make up the dominant, received readings of the field of federal Indian law today. Under either of them, the assessment of any contemporary issue of federal Indian law is fraught with peril. The doctrinal snags are difficult to untangle, and

7 See Johnson v. McIntosh, 21 U.S. (8 Wheat.) 543,588 (1823). Indeed, one of the most insightful analyses of the relationship between federal law and American colonization remains that of Alexis de Tocqueville, who later wrote:

The Spaniards were. unable to exterminate the Indian race by those unparalleled atrocities which brand them with indelible shame, nor did they succeed even in wholly depriving it of its rights; but the Americans of the United States have accomplished this twofold purpose with singular felicity, tranquilly, legally, philanthropically, without shedding blood, and without violating a single great principle of morality in the eyes of the world. It is impossible to destroy men with more respect for the laws of humanity.

Alexis De Tocqueville, Democracy in America 355 (Phillips Bradley ed., I99o) (I835) (footnote omitted). For a discussion of de Tocqueville's take on the American treatment of racial minorities, see Randall Kennedy, Tocqueville and Racial Confict in America: A Comment, II HARV. BLACKLETTER J. I45, I45-53 (I994).

8 Johnson, 2I U.S. at 588.

9 See, e.g., L. Scott Gould, The Congressional Response to Duro v. Reina: Compromising Sovereignty and the Constitution, 28 U.C. DAVIS L. REv. 53, 58 (I994) (noting federal recognition of more than 300 American Indian tribes and 200 Alaska Native entities).

10 See, e.g., United States v. Wheeler, 435 U.S. 313, 323-24 (1978).

11 See infra pp. 1769-74.

12 Cf. Nell Jessup Newton, Let a Thousand Policy-Flowers Bloom: Making Indian Policy in the Twenty-First Century, 46 ARK. L. REv. 25, 27-28 (I993) (discussing Native American resistance to assimilation).

13 Frank Pommershem, Bram of Feathers: American Indian Law and ContempoRaRY Tribal LIFE 9 (1995). 
the normative problems associated with them remain daunting even a half-millennium after the first European contact with natives.

It is understandable, then, why a commentator analyzing a difficult question in the field might prefer to narrow the inquiry as much as possible by taking settled doctrines as given. Recently, Stuart Benjamin has done just that in his assessment of the constitutional questions surrounding the special legal treatment of Hawaiian natives. ${ }^{14}$ It is also understandable that a commentator might attempt to pierce the superstructure of confusion and identify a single explanatory value driving federal Indian law. L. Scott Gould has done so in his recent analysis of the last two decades of federal Indian law decisions. ${ }^{15}$

These seemingly disparate works are, in fact, the embodiment of two related kinds of analysis of federal Indian law. When Benjamin embarks on his evaluation of the constitutional status of preferences for Hawaiian natives, he understands his mission to be addressing a complicated issue that is, in principle, no different from any other knotty problem of public law. He is, then, doing what attorneys and courts ordinarily see themselves doing: the "normal science" of law. In contrast, when Gould undertakes his synthesis of recent Supreme Court decisions in federal Indian law, he seeks to transcend the normal science and identify (or construct) a paradigm. ${ }^{16}$ Gould's work is like Benjamin's in at least one key respect, however: it is descriptive rather than normative.

This analytic continuum - from what the law "is" on a certain issue to what it "is" when aggregated across a field - is, of course, not unique to federal Indian law. The essentially simultaneous appearance of these two analyses, however - both of which appear in prominent law reviews from which federal Indian law scholarship has been conspicuously absent ${ }^{17}$ - makes this a propitious time to rethink what federal Indian law is, where it is heading, and, ultimately, what it is supposed to be doing.

14 See Stuart Minor Benjamin, Equal Protection and the Special Relationship: The Case of Native Hawaiians, I06 YALE L.J. 537 (1996). For a summary of these legal preferences for Hawaiian natives, which arise under a combination of federal and state law and include land rights, educational benefits, and housing assistance, see id. at 552-58.

15 See L. Scott Gould, The Consent Paradigm: Tribal Sovereignty at the Millennium, 96 Colum. L. Rev. 809, 8I4-I5 (Ig96).

16 The terms "normal science" and "paradigms" are allusions to ThOMAS S. KUHN, THE Structure of ScIENTIFIC Revolutions Io, 43-5i (2d ed. I970).

17 Before the appearance of Benjamin's and Gould's works, the last article published in the Columbia Law Review or the Yale Law Journal on federal Indian law was Felix Cohen, The Erosion of Indian Rights, 1950-1953: A Case Study in Bureaucracy, 62 YALE L.J. 348 (1953). To be sure, both periodicals have included occasional student pieces on this topic, and the Columbia Law Review recently published an extended book review as well. See Alex Tallchief Skibine, Braid of Feathers: Phuralism, Legitimacy, Sovereignty, and the Importance of Tribal Court Jurisprudence, 96 Colum. L. REv. 557 (1996). 
In this Commentary, I use the work of Benjamin and Gould to identify some ubiquitous problems that lurk in the analysis of federal Indian law. When evaluated together, these assessments provide a remarkable window on the current state of the field, revealing an area of frustrating descriptive and normative complexity for practitioner and scholar alike. This unruliness of federal Indian law, I conclude, reveals some possibilities as well as problems for its evolution as it enters the next century. If litigation has proved incapable of rendering the field normatively attractive and conceptually coherent, there may be some structural explanation. In turn, focusing on the nature of the institutions and processes that shape federal Indian law may be more productive than doctrinal analysis in revealing pathways to reform. Indeed, the survival and current vitality of tribes as sovereigns, rather than simply as groups of subordinated people, make institutional alternatives to litigation not only possible, but also potentially empowering. Reconceiving of the field as establishing the framework for negotiation between sovereigns, rather than merely for litigation in federal courts, holds the promise both of greater participation by tribes in the formulation of the federal law that purports to govern them and of the evolution of a more normatively attractive and coherent approach.

\section{The Perils of Practice - or, Don't Believe EVERYTHING YOU READ}

The practice of federal Indian law shares all of the usual rewards, trials, and tribulations of public law practice - and then some. Among the more specialized challenges in the field have been the limited nature of relief available against federal deprivations of Indian rights, ${ }^{18}$ the problems of professional responsibility involved in representing a collective client whose decisionmaking board is subject to periodic change, ${ }^{19}$ and, until recently, the virtual absence of Native American attorneys. ${ }^{20}$ Benjamin's analysis of the constitutional issues concerning the special treatment of Hawaiian natives exposes a different, but more fundamental problem: unless injected with a heavy dose of historical perspective and legal realism, formal lawyerly analysis not only often fails to illuminate the issues in federal Indian law, but can also result in deceiving conclusions.

This is not the format in which to engage in a full-blown recitation and response to Benjamin's lengthy and complex assessment of the constitutionality of special measures concerning Hawaiian natives. Instead, for illustrative purposes, I examine one fundamental premise of

18 See, e.g., United States v. Mitchell, 463 U.S. 206, $216-17$ (1983); Nell Jessup Newton, Indian Claims in the Courts of the Conqueror, 4I AM. U. L. REv. 753, 754-854 (I992).

19 See, e.g., Edward Lazarus, Black Hills, White Justice: The Sioux Nation Versus the United States, 1775 to the Present 325-26, 366-67, 403-Io (I99i).

20 See, e.g., Clinton, supra note 3 , at gr. 
his argument: that a federal law that singles out and benefits a native group that is not formally recognized by the federal government as an "Indian tribe" should be subject to strict constitutional scrutiny as a suspect racial classification.

Benjamin's argument is straightforward. Under Adarand Constructors, Inc. v. Pena, ${ }^{21}$ federal classifications based on race are subject to strict scrutiny even if they benefit a racially subordinated group. ${ }^{22}$ To be sure, Morton v. Mancari ${ }^{23}$ recognizes that the federal government and Indian tribes have a special relationship, such that federal classifications based on tribal membership are political, not racial, $^{24}$ and are therefore subject only to a modified rational-basis test. ${ }^{25}$ Because, however, in Benjamin's judgment, Hawaiian natives and other native peoples who are not members of any federally recognized tribe fall outside the Mancari framework, classifications drawn to benefit them cannot claim the protective shelter of that precedent. ${ }^{26}$ Accordingly, the classifications are racial, strict scrutiny applies, and they are almost surely unconstitutional. ${ }^{27}$

Each of these conclusions is defensible, based on a lawyerly reading of current law. Each is, however, also rooted in legal fiction.

Take Adarand, for starters. As the Supreme Court has generally done since Bolling $v$. Sharpe, ${ }^{28}$ the Court in Adarand simply equated equal protection analysis of federal and state racial classifications. ${ }^{29}$ The obvious problem with this approach is that, by its text, the Equal Protection Clause applies only to the states, ${ }^{30}$ and it was in connection with state use of racial classifications that the Court began generally

21 II5 S. Ct. 2097 (1995).

22 See id. at 2117 .

23417 U.S. 535 (1974). The facts and holding of this case are discussed below at p. I762.

24 See id. at 553-54 \& n.24.

25 See id. at 555 ("As long as the special treatment can be tied rationaliy to the fulfillment of Congress' unique obligation toward the Indians, such legislative judgments will not be disturbed."). Although this formulation appears to be a modified rational-basis approach that might invalidate federal legislation harmful to tribes, in practice the Court has equated it with the garden-variety rational-basis test, under which essentially all legislation survives judicial scrutiny. See, e.g., Washington v. Confederated Bands and Tribes of the Yakima Indian Nation, 439 U.S. 463, 500-02 (1979); Delaware Tribal Bus. Comm. v. Weeks, 430 U.S. 73, 85-89 (1977).

26 See Benjamin, supra note 14 , at 558 .

27 See id. at 592-96.

28 See Bolling v. Sharpe, 347 U.S. 497, 499-500 (I954) (identifying an equal protection component of the Due Process Clause of the Fifth Amendment and using it to strike down school segregation in the District of Columbia).

29 See Adarand Constructors, Inc. v. Pena, Ir5 S. Ct. 2097, $2107-08$ (1995). To do so, the Court had to overrule Metro Broadcasting, Inc. v. FCC, 497 U.S. 547, 565-66 (I990), a rare recent precedent recognizing that the Fifth and Fourteenth Amendments should not be coextensive on equal protection limitations on federal and state legislative power. See Adarand, II5 S.

Ct. at $2 I_{12-I 4}$.

30 See U.S. CoNST. amend. XTV, § I. 
to strike down racial classifications. ${ }^{31}$ Thus, although in recent years the Court has repeatedly said that equal protection analysis is the same regardless of the federal or state nature of the racial classification, ${ }^{32}$ it is the Court, not the Constitution, that is the source of this conclusion. The Court has maintained, with a straight face, that there is something called the "equal protection component of the Due Process Clause of the Fifth Amendment,"33 a bit of textual and historical legerdemain that conveniently hides that the component is the product of the judges' mind, not the framers' hand. The short explanation is that this "component" is substantive due process by another name. ${ }^{34}$ True to his mission of assessing the constitutionality of classifications

31 See, e.g., Loving v. Virginia, 388 U.S. I, 2 (1967).

32 See Adarand, II5 S. Ct. at 2107-08 (reviewing the precedents).

33 United States v. Armstrong, II6 S. Ct. I480, I486 (I996).

34 By this, I simply mean that the locus of the limitation is the Due Process Clause and that the limitation itself is not procedural.

From the perspective of constitutional originalism, it seems generally accepted that there are serious, if not insurmountable, problems with according a complete parallelism between the equal protection required of the states by the Fourteenth Amendment and the procedural fairness required of the federal government by the Fifth Amendment. See, e.g., ROBERT H. BORK, THE Tempting of America 83-84 (Iggo); Paul Brest \& Sanford Levinson, Processes of CoNSTItutional Decisionmaking: CaSes and Materials 600-or (3d ed. I992); LAURENCE $H$. Tribe \& Michael C. Dorf, ON Reading the Constitution in5-I6 (I9gI). For nonoriginalist prudentialists such as myself, integrative interpretations of these clauses are possible, but they by no means mechanically lead to the "reverse incorporation" of the later-in-time equal protection mandate into the earlier-adopted due process limitation. I discuss my view on this issue briefly in note 60 below. For a more extended discussion, including some efforts to overcome the originalism objection, see, for example, Akhil Reed Amar, Constitutional Rights in a Federal System: Rethinking Incorporation and Reverse Incorporation in Patterson and Gitlow, in BENCHMARKS: Great Constitutional Controversies IN THE Supreme Court 7I, 79-86 (Terry Eastland ed., 1995); Kenneth L. Karst, The Fifth Amendment's Guarantee of Equal Protection, 55 N.C. L. Rev. 541, 546-52 (1977); Michael J. Perry, Brown, Bolling, \& Originalism: Why Ackerman and Posner (Among Others) Are Wrong, 20 S. ILL. U. L.J. 53, 69-72 (1995); and Steven G. Calabresi, Note, A Madisonian Interpretation of the Equal Protection Doctrine, gr YALE L.J. 1403, 1426-29 (1982).

A deep irony is that Justices Scalia and Thomas, whose votes were critical to the outcome in Adarand, are the Justices most prone to complain about judicial activism and the creation of constitutional doctrines unrelated to the "real" Constitution, see, e.g., United States v. Virginia, II6 S. Ct. 2264, 2292 (I996) (Scalia, J., dissenting); Romer v. Evans, II6 S. Ct. I620, I629 (I996) (Scalia, J., joined by Rehnquist, C.J., and Thomas, J., dissenting), and, in particular, about the mythic, oxymoronic, unprincipled, and unauthorized qualities of substantive due process, see, e.g., BMW of N. Am., Inc. v. Gore, II6 S. Ct. 1589, r610-I6I2 (I996) (Scalia, J., joined by Thomas, J., dissenting); United States v. Carlton, 512 U.S. 26, 4I-42 (1994) (Scalia, J., joined by Thomas, J., concurring in the judgment); Planned Parenthood of Southeastern Pa. v. Casey, 505 U.S. 833, 980-82 (1992) (Scalia, J., joined by Rehnquist, C.J., and White and Thomas, JJ., concurring in the judgment in part and dissenting in part); Cruzan v. Director, Mo. Dep't of Health, 497 U.S. 26I, 293 (1990) (Scalia, J., concurring). This inconsistency between the conceptualization of the judicial role in the abstract and its application in reviewing federal affirmative action measures under an unwritten equal protection component has not gone unnoticed. See, e.g., Frank H. Easterbrook, Abstraction and Authority, 59 U. CHI. L. REv. 349, 356-58 (1992). 
based on Hawaiian-native status within existing precedents, ${ }^{35}$ however, Benjamin mentions not a hint of the fictional nature of this invocation of the Fifth Amendment.

Morton v. Mancari fares equally poorly when subjected to critical light. It is rooted in a double-barreled cluster of constitutional fictions, some purporting to support federal power over Indians in the first place, and others ignoring the ethnic quality of the classification at issue in that case.

The Court in Mancari assumed that there is a "special relationship" between the United States and Indian tribes. ${ }^{36}$ The source of federal authority to conduct this "relationship," the Court stated, is "[t]he plenary power of Congress to deal with the special problems of Indians . . .."37 The Court cited only two sources in the Constitution for this power: the Indian Commerce Clause and the treaty power. ${ }^{38}$ In truth, however, neither these clauses nor any other constitutional text justifies the conclusion that the plenary power is legitimate.

The first major plenary power case, United States v. Kagama, ${ }^{39}$ illustrates the extratextual quality of the federal plenary power over Indian affairs. At issue was the constitutionality of the Major Crimes Act of $1885,{ }^{40}$ which made it a federal crime for an Indian to commit any one of certain enumerated serious offenses on an Indian reservation. ${ }^{41}$ Congress adopted the statute in response to the Court's decision in Ex parte Crow Dog, ${ }^{42}$ which had held that no federal crime had occurred when one Indian murdered another on a reservation..$^{43}$ In Kagama, it was abundantly clear that neither of the sources of federal power later cited in Mancari justified the passage of the Major Crimes Act. The treaty clause was irrelevant because the tribe to which the defendant belonged had no treaty with the United States, ${ }^{44}$ much less one ceding to the United States a local police power over tribal affairs. Moreover, the Court in Kagama itself rejected the argu-

35 See Benjamin, supra note 14 , at $54^{\mathrm{r}-42}$ (limiting his inquiry to the status of Hawaiian natives under current law).

36 Morton v. Mancari, 4I7 U.S. 535, 552 (1974).

37 Id. at $55 \mathrm{r}$.

38 See id. at 552. "The Congress shall have Power . . To regulate Commerce with foreign Nations, and among the several States, and with the Indian Tribes ...." U.S. ConsT., art. I, § 8, cl. 3. "[The President] shall have Power, by and with the Advice and Consent of the Senate, to make Treaties, provided two thirds of the Senators present concur . . ." Id. art. II, \& 2, cl. 2.

39 II8 U.S. 375 (1886).

40 Major Crimes Act of I885, ch. 34I, § 9, 18 U.S.C. $\S$ II53 (I994).

41 See id.

42 I09 U.S. 556 (1883).

43 See id. at 572.

44 See Nell Jessup Newton, Federal Power Over Indians: Its Sources, Scope, and Limitations, 132 U. PA. L. REV. I95, 213-I4 (1984). 
ment that the Major Crimes Act was sustainable as a regulation of "commerce" with that tribe. 45

In the absence of any constitutional grant of power to Congress to regulate on this subject, conventional constitutional doctrine would seemingly have required the Court to strike down the statute at issue in Kagama. ${ }^{46}$ Nonetheless, the Court upheld the constitutionality of the statute, concluding that the Indians were helpless wards subject to plenary congressional control. ${ }^{47}$ In an earlier work, I have suggested that a close examination of the Kagama opinion, along with later precedents involving both Indian affairs and immigration, demonstrates that the Court implicitly embraced the notion that power over Indian affairs is an unwritten, inherent power of national sovereignty necessitated by the colonial nature of the United States. ${ }^{48}$ It is possible that the federal power, so understood, can be justified in some limited sense, but the argument for it is both elaborate and controversial. ${ }^{49}$ In short, although the congressional-power aspects of Mancari might be slightly less rooted in fiction than the equal protection limitations on federal lawmaking recognized in Adarand, neither is compatible with conventional constitutional interpretation.

Like all modern cases in this field, ${ }^{50}$ the Court in Mancari did not stop to ponder whether its assumption of federal plenary power over Indian affairs was based on fiction. Instead, it purported to limit the reach of this fiction by invoking another fiction - the unwritten equal protection component of the Due Process Clause of the Fifth Amend-

\section{The Court stated:}

[W] think it would be a very strained construction of this clause, that a system of criminal laws for Indians living peaceably in their reservations, which left out the entire code of trade and intercourse laws justly enacted under that provision, and established punishments for the common-law crimes of murder, manslaughter, arson, burglary, larceny, and the like, without any reference to their relation to any kind of commerce, was authorized by the grant of power to regulate commerce with the Indian tribes.

United States v. Kagama, II8 U.S. 375, 378-79 (1886). This conclusion retains contemporary force. See United States v. Lopez, II5 S. Ct. r624, I63I (I995) (holding that Congress has no authority under the Interstate Commerce Clause to enact a statute criminalizing possession of a gun near a school).

46 See McCulloch v. Maryland, I7 U.S. (4 Wheat) 316, 405 (18I9) (inding that congressional authority consists only of those powers delegated to Congress in the Constitution).

47 See Kagama, 118 U.S. at 383-84.

48 See Philip P. Frickey, Domesticating Federal Indian Law, 8I MiNN. L. REv. 3I, 58-69 (1996).

49 See id. at 70-72 (expressing concern that, if power over Indian affairs is conceptualized as "inherent," it could be viewed as extraconstitutional and thereby subject to no limitation).

50 See, e.g., Cotton Petroleum Corp. v. New Mexico, 490 U.S. 163, 192 (I989) (stating that the "central function of the Indian Commerce Clause is to provide Congress with plenary power to legislate in the field of Indian affairs"); McClanahan v. Arizona State Tax Comm'n, 4Ir U.S. I64, I72 n.7 (1973) ("The source of federal authority over Indian matters has been the subject of some confusion, but it is now generally recognized that the power derives from federal responsibility for regulating commerce with Indian tribes and for treaty making."). 
ment. $^{51}$ The Court in Mancari concluded that no serious equal protection values were implicated in the case.52 This was so because the classification at issue - giving Indians a hiring and promotion preference for positions in the federal Bureau of Indian Affairs (BIA) benefited members of federally recognized tribes, not ethnic Indians in general, and thus was a political rather than a racial classification. ${ }^{53}$ Unfortunately, this method of avoiding the application of heightened scrutiny is every bit as fictional as the other aspects of Adarand and Mancari. ${ }^{54}$

The employment preference in question in Mancari was for "qualified Indians,"155 and the statute defined "Indians" as members of federally recognized Indian tribes and "all other persons of one-half or more Indian blood."56 The Court in Mancari completely ignored the facts that the statute allowed an ethnic Native American who was not a member of a recognized tribe to qualify for the preference, and that her entitlement to it turned on blood quantum - seemingly a graphic invocation of race qua race that, in other contexts, Justices have railed against as exhibiting the worst, most offensive aspect of categorization by innate characteristic. ${ }^{57}$ Instead, the Court fixated upon the BIA implementing regulation, which, as the Court noted, "applies only to members of 'federally recognized' tribes." Th8 This description was at best only partly accurate, however. The regulation provided that, to be eligible for the preference, "an individual must be one-fourth or more degree Indian blood and be a member of a Federally-recognized tribe."59 Even under the regulation, then, race, as measured by blood quantum, was a but-for requirement of eligibility for the preference. The Court in Mancari did not pause to ponder this problem.

To be sure, there might well be better arguments for defending the outcomes in Adarand or Mancari.60 But Benjamin "addresses the con-

51 See Morton v. Mancari, 4I7 U.S. 535, 55 I (1974).

52 See id. at $553-55$.

53 See id. at $553-54 \&$ n.24.

54 For an early and probing assessment of this problem, see Newton, cited above in note 44, at $27 \mathrm{I}-88$.

55 Indian Reorganization Act § I2, 25 U.S.C. § 472 (1994).

5625 U.S.C. $\S 479$ (I994).

57 See, e.g., Metro Broadcasting, Inc. v. FCC, 497 U.S. 547,633 n.I (r990) (Kennedy, J., dissenting); Fullilove v. Klutznick, 448 U.S. 448, 531-32 (1980) (Stewart, J., dissenting); id. at 534 n.5 (Stevens, J., dissenting).

58 Mancari, $4{ }^{17} 7$ U.S. at 553 n.24.

5944 Bureau of Indian Affairs Manual 335, § 3.I, quoted in Mancari, 417 U.S. at 553 n.24.

60 One place to begin would be identifying the extent to which, if at all, the Fifth Amendment should contain any implicit equal protection limitation. Bolling v. Sharpe, 347 U.S. 497 (I954), was cavalier in this regard: the Court justified its conclusion by positing that it would be "unthinkable" that the federal government could engage in school segregation but a state could not. See id. at 500. Although I claim no fully informed theory on this question, I am attracted to Justice Stevens's view that the Due Process Clause of the Fifth Amendment is capacious enough to embody a limited rationality constraint that calls into question, but does not automatically 
stitutional status of legislation giving benefits to Native Americans under current case law and so [does] not consider arguments that reject the prevailing jurisprudence." 161 Unlike most legal scholarship today, he attempts to define what the law is as objectively and nonnormatively as possible, and to leave it at that. He does not address the assumptions and analytical moves that have led the law to this point, the degree to which this point can be considered indeterminate in light of the doctrinal incoherence, and the wider alternatives.

A fundamental problem with using this kind of limited analysis in federal Indian law may be seen in Benjamin's argument that benefits for indigenous persons may be provided only to members of Indian "tribes."62 Benjamin's claim is that the tribal-membership requirement flows from two conclusions in Mancari. The first is that, for purposes of the statute at issue in that case, the plenary power over Indian affairs was rooted in the Indian Commerce Clause, which provides Congress the authority to regulate commerce "with the Indian Tribes." 63 The second is that the preference in Mancari was not racial because it flowed only to members of tribes, which are political organizations. These two conclusions lead nowhere, however, for three reasons. First, by its text, the Indian Commerce Clause cannot possibly be the source of a plenary power over Indian affairs: indeed, the clause was rejected as the source of this all-encompassing congressional power in Kagama. ${ }^{64}$ This would seem to undercut any need to emphasize the word "tribe" from an Article I perspective. Second, the other aspect of Mancari - that tribal affiliation renders the preference political, not racial - is equally undercut by the fact that blood quantum was a but-for requirement of the preference. ${ }^{65}$ Third, and more generally, in an area in which the judicial attention to rule-of-law values has been so lax, why should analysis be strictly tied to a literalist interpretation

invalidate, any congressional classification based on suspect criteria that the Equal Protection Clause prevents states from using. See Hampton v. Mow Sun Wong, 426 U.S. 88, I03 (I976). When the federal government operates much like a state, as it did in Bolling in its oversight of the District of Columbia's schools, the rationality of the federal action should depend on whether similar state action would be considered illegitimate. When the federal government carries out an exclusively national function, however, such as engaging in relations with Indian tribes, its use of classifications that are sensitive when used by states in other contexts is not so inherently suspicious. This would seem especially true for such classifications that benefit rather than harm a subordinated group, such as Indians.

The other problem left unanswered in Mancari is, of course, where, if anywhere, Congress is provided with a plenary power to govern Indian affairs. For my thoughts on this question, see Frickey, cited above in note 48 , at $52-74$.

61 Benjamin, supra note 14 , at 543 n.23.

62 See id. at 558-92.

63 U.S. CoNST. art. $x, \& 8$, cl. 3 (emphasis added).

64 See supra pp. I760-61.

65 See supra pp. I76r-62. 
of one word in the Indian Commerce Clause and one questionable precedent? 66

To be sure, the reader who is weary of scholarly navel-gazing and rootless normativity might welcome Benjamin's approach. The problem remains, however, that the weak substructure of Adarand and Mancari cannot support the dense superstructure of analysis that Benjamin creates. He comes perilously close to saying, with the Wizard of $\mathrm{Oz}$, that the reader should pay no attention to what is behind the curtain. Yet Dorothy and her entourage would have done rather more poorly had they relied on a deferential analysis of the apparent, rather than a critical analysis of the real.

My criticism is not meant as much as an attack on Benjamin's effort as a demonstration of a larger point about the intractable problems that arise when using lawyerly analysis in federal Indian law. The area is so complex and convoluted that the practitioner should not simply bring the general skills of the excellent lawyer to it without leavening the analysis with a broader sense of where the field came from and where it might be heading. The opinion in Mancari itself noted "the unique legal status of Indian tribes under federal law."67 Nearly a century before, in Kagama, the Court had more frankly acknowledged that the relation of tribes to the United States government "has always been an anomalous one and of a complex character." ${ }^{.68}$ The field is so rife with judicial deference to congressional plenary power that the Supreme Court has struck down as unconstitutional federal statutes regulating Indians only six times. ${ }^{69}$ To import generic equal protection theories - themselves, as Adarand indicates, subject to criticism even on their own terms - into federal

66 Benjamin assumes, as did the Court in Mancari, that the special or trust relation is between tribes and the United States, not between indigenous persons and the United States. See Benjamin, supra note I4, at 545. But $f$. Lone Wolf v. Hitchcock, I87 U.S. 553, 568 (1903) (finding "a mere change in the form of investment of Indian tribal property" when Congress unilaterally divided up an Indian reservation into allotments for individual tribal members and thus seeming to conclude implicitly that the trust relationship existed between the United States and individual Indians, not tribes). See also Carole Goldberg-Ambrose, Not "Strictly" Racial: A Response to "Indians as Peoples", 39 UCLA L. REv. 169, 189-90 (r99r) (suggesting that the trust relationship should extend to all descendants of those originally victimized by colonization).

67 Morton v. Mancari, 417 U.S. 535, 55r (1974).

68 United States v. Kagama, Ir8 U.S. 375, 38I (1886).

69 Two of the cases involved federal schemes, each held to constitute an unconstitutional taking, under which a small fractional share of an individual Indian allotment would escheat to the tribe. See Babbitt v. Youpee, II7 S. Ct. 727, 729 (1997); Hodel v. Irving, 48x U.S. 704, 717-18 (I987). Two other, much older cases also involved an unconstitutional taking of individual Indians' property. See Choate v. Trapp, 224 U.S. 665, 678-79 (1912); Jones v. Meehan, I75 U.S. I, 32 (1899). The final two cases involved structural constitutional defects. See Seminole Tribe v. Florida, II6 S. Ct. II 44, II3I-33 (I996) (invalidating, under the Eleventh Amendment, a statute that subjected states to suit in federal court); Muskrat v. United States, 219 U.S. 346, 361-63 (1911) (invalidating a statute that called on federal courts to issue advisory opinions). The Court has never invalidated any federal measure on the ground that it invades tribal sovereignty. 
Indian law constitutes an error of significant magnitude, for it confuses a puzzling, conceptually intractable, and little-understood corner of public law with its mainstream.

I am not suggesting, along the lines of the old joke sometimes repeated by federal Indian law scholars and practitioners, that there is (or should be) an "Indian exception to the Constitution." What I mean to suggest is that any meaningful and intellectually coherent constitutional analysis in this field cannot simply follow the customary lawyerly path of beginning today and working backward only to the extent that recent precedent seems to leave open questions. Instead, working forward from the beginning is profoundly enlightening in federal Indian law. The Constitution became possible only by virtue of colonization, and the document rests awkwardly on top of that history. The deep irony is that we live in a society governed by a constitution that is based on a social contract theory of consent and that protects rights to liberty and property, yet made possible only by unilaterally dispossessing Natives of their autonomy and lands. The inconsistencies only become more awkward when the Constitution itself is closely examined, for it provides no textual hint of the plenary power over Indian affairs that Congress has confidently exercised for a century and courts have routinely validated.70

To make sense of the field - and any important issue in it requires, I believe, asking why judges have deferred to such sweeping exercises of congressional authority. It cannot be, after all, that conventional constitutional interpretation easily justifies such judicial reticence. If it is not based upon values traditionally rooted in the rule of law, then what might be an alternative basis? And whatever that alternative basis might be, is it not just a bit awkward to apply conventional lawyering analysis to a field that, at its core, is bereft of it?

Notwithstanding being caught betwixt and between the mythologies of Adarand and Mancari, the practitioner might well feel that her role is to provide an objective and non-normative analysis of how current courts are likely to resolve the issue under consideration. Benjamin takes this tack, ultimately seeing his mission as determining where the Supreme Court "is" on the issue. But his predictive lens provides focus only through the lawyerly analysis of precedents, rather than through an examination of the potential non-doctrinal explanations for those precedents. Might not the longstanding judicial reluctance to intervene in Indian affairs lead even the practitioner who views her role as wholly predictive to conclude that, notwithstanding the lawyerly ar-

70 Indians are mentioned only three times in the Constitution: in the Indian Commerce Clause, see U.S. CoNST. art. I, $\$ 8, \mathrm{cl} .3$, and in two provisions directing that "Indians not taxed" are to be excluded in apportioning the House of Representatives, id. art. I, $\$ 2, \mathrm{cl} .3$; id. amend. $\mathrm{XTV}, \S 2$. 
guments for the unconstitutionality of special legislation singling out Native Americans, the courts are unlikely to pull the trigger?

In fact, the precedent upon which Benjamin relies, Adarand, suggests that judicial deference might continue to be forthcoming, despite the supposedly unavoidable logic of the argument for unconstitutionality. Indeed, Adarand is marvelously malleable concerning the constitutionality of preferences for Native Americans, such as those in Mancari. The Court in Adarand began by expressing a remarkably color-blind perspective: "[A]ny preference based on racial or ethnic criteria must necessarily receive a most searching examination."11 $\mathrm{Be}$ cause Native American blood quantum is a but-for requirement of the preference in Mancari, it would seem to be the sort of racial criterion specified in Adarand. Later in the Adarand opinion, however, the Court signaled a reluctance to reopen issues in fields "in which we found special deference to the political branches of the Federal Government to be appropriate."12 As an example, the Court cited Hampton $v$. Mow Sun Wong, ${ }^{73}$ a case involving federal regulation of aliens. ${ }^{74}$ This cryptic reference suggests, at a minimum, that in the field of immigration law and alienage regulation, in which the Court has accorded Congress a plenary power, ${ }^{75}$ the Court will be reluctant to upset longstanding arrangements, even though they might arguably involve some discriminatory element.

Federal Indian law is, of course, also a field in which the Court has long accorded Congress plenary power. Indeed, in my judgment, it is far from a coincidence that plenary power exists in both immigration law and federal Indian law: there are parallel reasons for plenary power in both. ${ }^{76}$ Might this not leave Mancari good law despite its tension with Adarand? And if judicial deference remains the norm in federal Indian law, might not the courts defer to federal policies toward Indians even if, as Benjamin argues, they do not fit within the four corners of Mancari? Otherwise, many longstanding arrangements might be called into question. The opinion in Mancari supports this prudential notion of judicial deference, expressing concern that a contrary holding might jeopardize the constitutionality of "an entire Title

11 Adarand Constructors, Inc. v. Pena, II5 S. Ct. 2097,2100 (1995) (quoting Wygant v. Jackson Bd. of Educ., 476 U.S. 267,273 (I986) (quoting Fullilove v. Klutznick, 448 U.S. $448,49 \mathrm{I}$ (I980))).

72 Id. at 2108 .

73426 U.S. 88 (r976).

74 See Adarand, Ir5 S. Ct. at 2 I08.

75 For a recent overview, see Stephen H. Legomsky, Ten More Years of Plenary Power: Immigration, Congress, and the Courts, 22 HASTINGS ConST. L.Q. 925, 925-37 (1995).

76 See Frickey, supra note 48 , at $52-74$ (suggesting that plenary power over immigration is an inherent power under international law of all sovereigns to control the influx of "foreigners," and that the plenary power over Indian affairs is a similar inherent power of those sovereigns that were created by colonization to control "foreigners" who were already present - that is, indigenous persons). 
of the United States Code"77 as well as "the solemn commitment of the Government toward the Indians." " 8

In the first published decision on the constitutionality of special preferences for Hawaiian natives, the federal district court equated such preferences with those for Native Americans in the continental United States and rejected the constitutional challenge to them..$^{79}$ Why? Simply because "Native Hawaiians are people indigenous to the State of Hawaii, just as American Indians are indigenous to the mainland United States."80 In other words, it was a federal Indian law case, with all of the customary backdrop of history, complexity, and judicial deference. Peeking behind that curtain would be, to mix metaphors, like opening a can of worms. As for the question of what law supports such summary judicial restraint, one might cite one of the oldest of prudential laws - the law of avoiding unanticipated consequences.

This is not the place for a complete defense of the constitutionality of federal classifications based upon Indian heritage, much less for the creation of a broader theory of federal Indian law that might smooth out the central analytical problems - not to mention the conceptual rough edges - of the field..$^{81}$ Instead, what I hope to have demonstrated is that, in federal Indian law, lawyerly analysis that is devoid of broader historical and theoretical perspectives leads to misleading conclusions about the determinacy and substance of what the law "is" at any given moment. More specifically, whatever might be true of mainstream public law, and however much the pristine practitioner might abhor it, what is popularly called "politics" has a strong explanatory and predictive value in federal Indian law. To assess current questions in Indian affairs as merely matters of abstract, backwardlooking doctrinal analysis is to confuse a counterhistorical ideal of the rule of law with the reality of a complicated politico-legal, historical, and institutional "situation sense." 82 What results is illusory law without life - mere conceptual constructs instead of the complicated

77 Morton v. Mancari, 4 I7 U.S. 535, 552 (I974) (referring to 25 U.S.C.).

78 Id.

79 Naliielua v. Hawaii, 795 F. Supp. 1009, Ior3 (D. Haw. 1990), affd on other grounds, 940 F.2d I535 (9th Cir. I99I). The only other published decision is Rice v. Cayetano, 94I F. Supp. I529 (D. Haw. I996), which provided a somewhat more elaborate equal protection analysis but, in the end, relied upon Naliielua in upholding a classification based upon Hawaiian native status. See id. at $5539-43$.

80 Naliielua, 795 F. Supp. at ror3.

81 For my own attempts to reconceptualize the major issues in the field, see Frickey, cited above in note 4, at II37-I240; Frickey, cited above in note 48, at 3I-95; and Philip P. Frickey, Marshalling Past and Present: Colonialism, Constitutionalism, and Interpretation in Federal Indian Law, Io7 HARV. L. REv. 381, 381-440 (I993).

82 On the importance of "situation sense," see KARL N. Llewelzyn, The Common Law Tradition: Deciding Appeais 59-61, 12 I-57, 206-08 (Ig60). 
calculus of doctrinal and human factors that coalesce to form federal Indian law.

It would be interesting to conduct an experiment in which doctrinal analytics replace legal realism in federal Indian law lock, stock, and barrel. Because many of the central doctrines in the field are devoid of convenient legal justification, an ascetic doctrinal approach driven by mainstream public law values could turn the field topsyturvy. For example, Congress might no longer have a plenary power over Indian affairs, and tribes might no longer be locked into an involuntary trust relationship with the federal government, which has long been used to justify paternalistic statutes and regulations. Until that redemptive day (the second coming of Columbus?) comes, however, it makes no sense to allow abstract doctrinal analysis to claim a fraction of the field - especially when the doctrinal conclusions that are reached by this method harm Native Americans - while leaving the remainder of it controlled by the unholy trinity of history, power, and incoherence.

\section{The Perils of Paradigmatics - or, Sometimes There's Less Than MeEts THE Eye}

If narrow doctrinal analysis is fraught with peril in federal Indian law, then a broader sort of inquiry might seem appropriate. L. Scott Gould has recently engaged in a wide-ranging analysis of the field that seeks to identify the central value at its heart. ${ }^{83}$ His work contains important insights. Unfortunately, in my judgment, he falls victim, as did Benjamin, to the desire to impose an artificial coherence upon the field.

Gould's thesis is as follows: "The consent paradigm states that absent a congressional delegation of authority, federal preemption, or a finding of inherent civil jurisdiction, the sovereign rights of tribes are sufficient to prevail in disputes between tribes and tribal members only."84 This statement is a useful description of many aspects of current federal Indian law. It is difficult, however, to accept it as a paradigm. On its own terms, Gould's thesis is riddled with exceptions that deprive it of the quality of a coherent theoretical framework for a field of inquiry. Moreover, those aspects of federal Indian law that it does describe cannot be conceptualized as rooted in any consistent understanding of "consent."

Sovereignty connotes authority over a region and the people within it. ${ }^{85}$ Recent federal Indian law cases have shown a trend away from conceptualizing tribal sovereignty as including this traditional geo-

83 See Gould, supra note 15 , at 8ro-902.

84 Id. at 854 .

85 See, e.g., Duro v. Reina, 495 U.S. 676, 685 (1990). 
graphic component. ${ }^{86}$ Instead of having sovereignty over their reservations such that tribal laws apply to all persons found within them, in some circumstances tribes have authority only over their members. ${ }^{87}$ The Supreme Court has suggested that tribal authority over nonmembers can be legitimated, if at all, only by their consent. ${ }^{88}$ The Court has even stated that "[ $t]$ he retained sovereignty of the tribe is but a recognition of certain additional authority the tribes maintain over Indians who consent to be tribal members." 89

If this dictum were credited, Gould might well be correct that a paradigm based on an overall conception of consent is at work in federal Indian law. 90 The dictum is quite wide of the mark descriptively, however, as is revealed by Gould's own model, which recognizes three exceptions to the rule. These exceptions, not the Court's loose language, are accurate representations of the field today. Although recognition of these exceptions enhances Gould's contribution as a descriptive matter, it undermines his attempt at paradigm-building.

Within the confines of this Commentary, I will illustrate the degree to which Gould's analysis cannot function as a paradigm by examining one of the exceptions he recognizes: that tribes have some sort of "inherent civil jurisdiction." 91 An assessment of this jurisdiction. requires surveying some of the recent decisions that have denied tribal sovereignty, as well as several others that have recognized it.

The modern decline of tribal geographical sovereignty can be traced from Oliphant v. Suquamish Indian Tribe,,$^{92}$ in which the Court held that a tribe could not exercise criminal jurisdiction over a nonIndian who had committed a crime on its reservation..$^{93}$ Over a decade later, in Duro v. Reina,${ }^{94}$ the Court applied the Oliphant rationale to deny tribal criminal jurisdiction over a nonmember Indian - that is, a Native American who was a member of a tribe other than the one seeking to prosecute him. ${ }^{95}$ The upshot of both decisions is that a tribe's criminal jurisdiction is limited to its members.

${ }^{86}$ See Allison M. Dussias, Geographically-Based and Membership-Based Viezs of Indian Tribal Sovereignty: The Supreme Court's Changing Vision, 55 U. PITT. L. Rev. I, 4 (I993).

87 See infra pp. 1769-70.

88 See Dussias, supra note 86 , at 4.

89 Duro, 495 U.S. at 693.

90 A problem is that the dictum refers to the "retained" sovereignty of tribes and does not purport to describe what additional sovereignty may be delegated to a tribe. See generally United States v. Mazurie, 4I9 U.S. 544, 554-59 (I975) (upholding congressional delegation to tribe of the authority to regulate liquor licensing in Indian country, even with respect to nonmembers who have not individually consented).

91 See supra p. 1768.

92435 U.S. 191 (1978).

93 See id. at 212.

94495 U.S. 676 (1990).

95 See id. at $695-96$. 
In both Oliphant and Duro, the denial of geographical jurisdiction was all the more striking because the nonmember in question had not merely committed a crime on the reservation as a transient, but actually lived there. To say that neither nonmember had "consented" to tribal criminal jurisdiction is to use that term in a way that is not ordinarily within the countenance of jurisdictional inquiries: 96 voluntary situs within a jurisdiction is ordinarily enough to provide that sovereign with the authority to apply its laws.97

What was lacking in Oliphant and Duro was not "consent" in the traditional sense, but membership in the political community that sought to impose its laws. Both cases stressed the civil-liberties concerns of permitting an American citizen to be prosecuted within the borders of the United States by a tribe in which that citizen had no right to vote and whose juries consisted solely of tribal members.98 That a sense of political community, not "consent" in the traditional understanding, controls both cases is evident when one recognizes that, under these cases, the only "consent" that seems to be legally operative is the consent of the governed.99 This limitation is rooted in a radically diminished conception of tribal sovereignty, not in the absence of non-Indian consent to jurisdiction.

- 96 In addition, in Oliphant, the Court noted that signs at the entrance to the reservation notified the public that entry would be deemed implied consent to tribal criminal jurisdiction. See Oliphant, 435 U.S. at $193-94$ n.2.

97 See Burnham v. Superior Court, 495 U.S. 604, 619 (1990) (obtaining personal jurisdiction by service of process upon person voluntarily present in jurisdiction comports with traditional notions of fair play and substantial justice).

98 See Duro, 495 U.S. at 692-94; Oliphant, 435 U.S. at $210-11$.

99 Oliphant held that "Indians do not have criminal jurisdiction over non-Indians absent affirmative delegation of such power by Congress," 435 U.S. at 208, and Duro simply extended that approach to criminal jurisdiction over nonmember Indians. Duro explicitly linked the jurisdictional holding to a theory of political community:

Retained criminal jurisdiction over members is accepted by our precedents and justified by the voluntary character of tribal membership and the concomitant right of participation in a tribal government, the authority of which rests on consent. . . With respect to . . . internal laws and usages, the tribes are left with broad freedom not enjoyed by any other governmental authority in this country. ... This is all the more reason to reject an extension of tribal authority over those who have not given the consent of the governed that provides a fundamental basis for power within our constitutional system.

Duro, 495 U.S. at 694 (citations omitted). Nonetheless, in Duro, the Court did state: "We have no occasion in this case to address the effect of a formal acquiescence to tribal jurisdiction that might be made, for example, in return for a tribe's agreement not to exercise its power to exclude an offender from tribal lands." Id. at 689.

Congress responded to Duro by acknowledging tribal criminal jurisdiction over nonmember Indians. See Act of Oct. 28, 1991, Pub. L. No. 102-137, ro5 Stat. 646 (making permanent the short-term approach adopted in Department of Defense Appropriations Act of 199I, Pub. L. No. rOI-5II, \& 8077, I04 Stat. 1856, I892-93 (1990) (amending 25 U.S.C. \& 1301 (1988))). For conflicting views of the constitutionality and wisdom of this measure, see Gould, cited above in note 9 , at 55-163 (con), and Nell Jessup Newton, Permanent Legislation to Correct Duro v. Reina, 17 AM. INDIAN L. REV. 109, 109-27 (1992) (pro). 
Had this approach to tribal sovereignty prevailed outside the arena of criminal jurisdiction, it would have established a "membership," not a "consent," paradigm of tribal authority. In other areas, however, tribal sovereignty over nonmembers remains more vibrant. These areas embrace more conventional conceptualizations of consent, which do not turn on whether the person whom the tribe wishes to regulate has consented through membership in the tribe. The nature of non-Indian consent in such areas, however, seems to be only one factor in a judicial balancing of relevant interests.

Non-Indians who enter a reservation and buy products there may be subjected to a tribal sales tax. ${ }^{100}$ This conclusion is merely an application of the conventional jurisdictional notion of consent to sovereign authority based on voluntary presence. As a matter of a theory of consent, however, it cannot be squared with Oliphant and Duro, which rejected such an approach to tribal criminal jurisdiction. The difference in the two lines of cases is probably this simple: the taxation of a transient transaction raises no serious civil-liberties concerns, for the transient non-Indian may avoid the tax by simply declining to enter into the transaction and by avoiding reservation transactions in the future. Because the civil-liberties concerns are minor, consent in the traditional sense is sufficient to provide a tribe with the authority in question.

Not all scenarios of tribal taxation of nonmembers are so simple, however. In Merrion v. Jicarilla Apache Tribe, ${ }^{101}$ the tribe had entered into long-term mineral leases with non-Indian companies under which the latter would extract oil and gas from tribal lands and pay a royalty to the tribe. Many years after the leases were signed, the tribe adopted an ordinance imposing a severance tax on oil and gas production on tribal land. The practical economic effect of the tax was to increase overall tribal income at the expense of nonmembers. ${ }^{102}$

This assertion of tribal authority seems rather far afield from the sales tax example. Unlike the sales tax scenario, the non-Indian companies in Merrion had no easy way to walk away from the transaction - they may well have incurred substantial reliance expenses on their understanding that the oil leases provided the precise parameters of their economic relationship with the tribe. The transaction was not a one-shot deal that could be easily avoided in the future; instead, it was a long-term contractual relationship. ${ }^{103}$

100 See Washington v. Confederated Tribes of the Colville Reservation, 447 U.S. I34, I53 (1980).

101455 U.S. 130 (Ig82).

102 See id. at 167 (Stevens, J., dissenting).

103 Nor is it necessarily the case, as the Court suggested in Merrion, that the tribal severance tax was similar in impact to a state severance tax imposed on the extraction of natural resources. See Merrion, 455 U.S. at 138 . To be sure, the existence of such state taxes might have provided the oil companies in Merrion with some notice that the tribe might attempt a similar scheme, 
Nonetheless, the Court in Merrion upheld the tribe's authority to impose the severance tax. ${ }^{104}$ The Court stressed that "there is a significant territorial component to tribal power"105 and that "[t]he power to tax is an essential attribute of Indian sovereignty because it is a necessary instrument of self-government and territorial management."106 It is patent, however, that precisely these rationales would uphold criminal jurisdiction in Oliphant and Duro.

Some notion of "consent" might seem to be the difference between Merrion and the criminal cases, but in fact there is little distinction between the cases based on traditional conceptions of this term. Recall that the nonmembers in the criminal cases lived on the reservation, and thus their manifestations of implied consent to jurisdiction were at least as strong as those of a non-Indian company that chose to engage in long-term business there. To be sure, the Secretary of the Interior had approved the severance tax in Merrion, but in a later case, in which no secretarial approval had been necessary, the Court reaffirmed the authority of the tribe to tax in similar circumstances.107 Thus, even the actual consent of the federal government - which otherwise might have been seen as some roundabout form of implied consent from nonmembers based upon their representation in that government $t^{108}$ - seems unimportant in explaining the differing outcomes in Merrion and the criminal cases. Finally, it may have seemed important to the Court in Oliphant that Congress had opened up some Indian reservations to nonmembers, thereby perhaps implicitly diminishing the power of the tribal political community ${ }^{109}$ Yet, in Merrion, the tribe itself had formally waived its power to exclude the non-Indian entity from the reservation in a document - the oil and gas lease - that provided not a hint that, by entering onto the reservation, the company might be subjected to a later, unilateral reformulation of the

thereby undercutting the reasonableness of their reliance on the silence in the mineral leases concerning taxation. Unlike the oil companies in Merrion, however, companies extracting oil from state government lands could have powerful allies who virtually represent them in the state legislature. This confluence of interests would arise if the common state constitutional requirement of uniformity in taxes, see, e.g., OKLA. CoNST. art. X, $\S 5$, were understood to require that state severance taxes be uniform across both private and state lands. On this understanding, a state severance tax could not be imposed solely on state lands, and its imposition across both state and private lands would incur the opposition of private royalty holders if their royalties would be reduced by the tax. No such persons or entities existed to represent the interests of the oil companies in Merrion in the tribal council, because the tribe was the only royalty holder.

104 See Merrion, 455 U.S. at 159.

$105 \mathrm{Id}$. at 142 .

106 Id. at 137 .

107 See Kerr-McGee Corp. v. Navajo Tribe of Indians, 47 I U.S. 195, 201 (1985).

108 See supra notes 90 and 99 (discussing congressional authority to delegate to tribes the power to regulate nonmembers).

109 See Gould, supra note 15, at 828-32, 843-44 (discussing the congressional allotment of Indian reservations, under which some reservation land became available for non-Indian settlement and ownership). 
deal. On this analysis, to suggest that there is some unified notion of consent at the heart of these cases becomes untenable. ${ }^{110}$

Another line of Supreme Court decisions, involving tribal-court civil jurisdiction, also provides an interesting challenge to building a paradigm based upon consent. In Williams $v$. Lee, ${ }^{111}$ the Court held that a non-Indian who sought to enforce a claim against an Indian on a transaction that was entered into on a reservation must bring suit in tribal court. ${ }^{112}$ In two later decisions, in which an Indian plaintiff sued a non-Indian defendant in tribal court for a tort that arose on a reservation, the Supreme Court declined to hold that the tribal court lacked subject-matter jurisdiction. ${ }^{113}$. Why this different approach to civil, as opposed to criminal, jurisdiction? The Court was unwilling to find an absolute bar to tribal-court jurisdiction in such civil cases because it concluded that, unlike in the criminal arena, there is no long history of assumptions by the federal government that no such civil tribal authority exists. ${ }^{114}$ Instead of denying jurisdiction over non-Indian defendants along the analogy of Oliphant, the Court constructed an approach requiring the exhaustion of tribal-court remedies before the case may enter federal court, after which the only federal issue is whether the tribal court erred in assuming jurisdiction, not whether its ruling on the merits was erroneous. ${ }^{115}$ In what way did the non-Indian plaintiff in Williams $v$. Lee and the non-Indian civil defendants in the later cases "consent" to tribal-court jurisdiction? Apparently, in the same way in which everyone else ordinarily consents to sovereign jurisdiction: voluntary presence within the geographical confines of the sovereign. ${ }^{116}$

110 This is not to suggest, however, that Merrion was wrongly decided. See infra note 127.

111358 U.S. 217 (1959).

112 See id. at 223 .

113 See Iowa Mut. Ins. Co. v. LaPlante, 480 U.S. 9, 19-20 (1987); National Farmers Union Ins. Co. v. Crow Tribe of Indians, 47 I U.S. $845,855-57$ (1985).

114 See National Farmers Union, 47 I U.S. at 853-55.

115 See Iowa Mutual, 480 U.S. at 16-I9.

116 The concern, so evident in Oliphant and Duro, see supra pp. I769-70, that the law to be applied and the judge and jury to be involved come from a political community to which the non-Indian cannot belong was not treated as an important factor in the civil cases involving nonIndian defendants. The Court in National Farmers Union did state, however, that exhaustion was not required when an assertion of tribal jurisdiction was motivated by bad faith or was frivolous. See National Farmers Union, 47 I U.S. at 856 n.21. In Iowa Mutual, the Court responded to a suggestion of bias by noting that "the Indian Civil Rights Act . . provides nonIndians with various protections against unfair treatment in the tribal courts." Iowa Mutual, 480 U.S. at I9 (citing the Indian Civil Rights Act, 25 U.S.C. § I302 (1994), which imposes on tribal governments many of the limitations on federal and state governmental action that are found in the Bill of Rights and the Fourteenth Amendment). The Indian Civil Rights Act would have equally protected non-Indian criminal defendants in tribal court, of course, and yet that protection was insufficient to persuade the Court in Oliphant to leave criminal jurisdiction in place. See Oliphant, 435 U.S. at I94 (noting the existence of Indian Civil Rights Act but stressing that "the guarantees are not identical" in tribal court and federal and state courts, including the fact that non-Indians "are excluded from Suquamish tribal court juries"). 
One final pattern of cases falls somewhere between the traditional conception of implied consent to sovereignty that is found in the tribal-court civil jurisdiction and tribal taxation cases and the denial of the power to consent that is found in the criminal cases. The Court has struggled, and thus far failed, to come up with a coherent approach for cases in which a tribe asserts civil authority to regulate the conduct of non-Indians on lands that they own in fee on its reservation. In Montana $v$. United States, ${ }^{117}$ in the context of attempted tribal regulation of non-Indian hunting and fishing on non-Indian fee lands that were located on a reservation, ${ }^{118}$ the Court first expressed a presumption against tribal authority to regulate nonmembers in these circumstances $^{119}$ and then stated that the presumption might be overcome by a showing either that the non-Indian had consented to tribal regulatory power or that the asserted tribal authority was especially important in the circumstances. ${ }^{120}$ In Brendale $v$. Confederated Tribes and Bands of the Yakima Indian Nation, ${ }^{121}$ four Justices rejected the notion that tribal regulatory authority over nonmember fee owners might turn on its importance to the tribe. ${ }^{122}$ Nonetheless, a fractured Court in that case upheld a tribe's authority to zone non-Indian fee lands located on a portion of the reservation that had retained its Indian character. ${ }^{123}$

117450 U.S. 544 (I98I).

118 When non-Indians are transients on the reservation enjoying hunting and fishing opportunities on tribal land, there is no doubt that they are subject to tribal regulation. See id. at $55 \%$.

119 See id. at 564 ("[E]xercise of tribal power beyond what is necessary to protect tribal selfgovernment or to control internal relations is inconsistent with the dependent status of the tribes, and so cannot survive without express congressional delegation.").

120 The Court in Montana stated:

A tribe may regulate, through taxation, licensing, or other means, the activities of nonmembers who enter consensual relationships with the tribe or its members, through commercial dealing, contracts, leases, or other arrangements. . . . A tribe may also retain inherent power to exercise civil authority over the conduct of non-Indians on fee lands within its reservation when that conduct threatens or has some direct effect on the political integrity, the economic security, or the health or welfare of the tribe.

Id. at 565-66 (citations omitted).

121492 U.S. 408 ( 1989 ).

122 See id. at 428-3I (opinion of White, J.). Three Justices took precisely the opposite tack, proposing an expansion of the approach so that it would become, in effect, a presumption of inherent tribal authority in any situation in which there is a "significant tribal interest." Id. at 457 (Blackmun, J., joined by Brennan \& Marshall, JJ., concurring in part and dissenting in part). Two Justices did not directly discuss the Montana approach. See id. at 443-44 (Stevens, J., joined by $\mathrm{O}^{\prime}$ Connor, J., announcing the judgment) (distinguishing Montana). A later majority opinion seemingly considered the Montana approach to be good law. See South Dakota v. Bourland, 508 U.S. 679,695 (1993).

123 The outcome in the Brendale case was controlled by the opinion of Justice Stevens, joined by Justice $O$ 'Connor, who believed that the tribe had the authority to zone nonmember fee land so long as the portion of the reservation containing it had not lost its essential Indian character. See Brendale, 492 U.S. at 441-44. For a critical examination of this case, see Joseph William Singer, Sovereignty and Property, 86 Nw. U. L. REv. I, I-56 (Ig91). 
When these criminal and civil cases are combined, it is difficult to conceptualize what emerges as a "consent paradigm." The criminal cases turn on a strong sense of the limits of political community, not on whether a particular non-Indian consented to tribal regulation. Anything short of actual membership in the tribal political community is insufficient to authorize the exercise of inherent tribal authority. In contrast, the taxation cases and the tribal-court civil jurisdictional cases take an inconsistent approach by following a more traditional notion that presence within a jurisdiction is at least presumptively sufficient to constitute consent to sovereign regulation. Finally, the civil regulatory cases are so incoherent as to defy any obvious explanation, or at least one based on any plausible notion of consent. ${ }^{124}$

Such erratic judicial behavior is often explainable as resulting from the application of an ad hoc balancing test.125 My own sense is that, in its federal Indian law jurisprudence, the Court has been doing nothing more than balancing the interests it perceives to be salient in the cases. The interests that the Court seems to find most understandable are on the non-Indian side of the case. The weightiest concern is the deprivation of liberty that arises from criminal sanction by a political community to which one not only does not, but cannot, belong. Second in importance seems to be interference with long-sacrosanct notions of property rights in fee-simple lands, perhaps especially in cases in which the non-Indian ownership of land in Indian country is longstanding and the result of express congressional policy. ${ }^{126}$ In contrast, when a non-Indian enters Indian country for transactional reasons, she is presumptively as much on her own as anyone entering a foreign jurisdiction would be. ${ }^{127}$

124 As this issue was going to press, the Supreme Court decided Strate v. A-I Contractors, II 7 S. Ct. ${ }_{204}$ (1997). The Court held that a tribal court had no jurisdiction over a tort action arising from an automobile accident between non-Indians on a state highway on an Indian reservation. The holding seems fact-specific: the Court equated a nonmember on a state highway to a nonmember on nonmember fee land and accordingly concluded that the presumption against tribal power created in Montane controlled. Indeed, the Court reserved the question of tribal-court jurisdiction over nonmembers on tribal roads. Despite these qualifications, however, the Court did "hold" that, with respect to nonmembers, "a tribe's adjudicative jurisdiction does not exceed its legislative jurisdiction," id. at I413, and treated National Farmers Union and Iowa Mutual as exhaustion cases, not jurisdictional cases, see id. at r4ro. Accordingly, Strate may have deflated the general presumption favoring tribal-court jurisdiction over nonmembers who are voluntarily present on reservation land which National Farmers Union and Iowa Mutual seemed to create. Strate is consistent with the trend denying tribal sovereignty that Gould identified, but the contours of this precedent remain subject to substantial uncertainty pending elaboration in the lower courts.

125 See, e.g., T. Alexander Aleinikoff, Constitutional Law in the Age of Balancing, 96 YALE L.J. $943,972-83$ ( 1987 ).

126 See supra p. 1772.

127 In Merrion v. Jicarilla Apache Tribe, 455 U.S. I30 (I982), for example, the issue boiled down to which party to the oil and gas lease should bear the responsibility for the silence in the lease concerning taxation. See id. at 145-47. Under ordinary principles of sovereignty, under 
On the tribal side of the balance, it is not at all clear what the Court is identifying and weighing as relevant factors. As Gould realized, the notion of non-Indian "consent" to tribal regulation is a thread running through these cases, but it is not the only factor, and it lacks a unitary understanding. Even if "consent" is viewed as an unartful way of identifying the cluster of factors surrounding the role of tribal membership or nonmembership, it fails to provide a unified descriptive model of the precedents. Nonmembership is becoming increasingly important, to be sure, but no coherent approach based on it runs through the cases. In short, despite Gould's efforts to the contrary, the decisions do not adequately resolve whether tribes should be conceptualized as sovereigns or membership associations. ${ }^{128}$

What a careful analysis of Gould's contribution reveals, I suggest, is that federal Indian law remains about as unruly as ever. Attempts to discipline it through a critical but descriptive lens are well worth the scholarly effort, but remain unlikely to reveal a unified theory. Moreover, a focus on descriptive rather than normative accounts of federal Indian law - the mission of Gould as well as Benjamin - is likely to miss the core problems of this field. Conflicting and confounding values, rather than simply a failure of judicial logic or technique, seem to be driving this incoherence. Indeed, the story of federal Indian law is one of vacillation between an approach rooted in respecting the uniqueness and worthiness of tribal institutions and one bent on assimilating tribes and their members into the larger society. ${ }^{129}$ On the whole, competing paradigms of uniqueness and uniformity provide, I believe, a much more illuminating picture of federal

which grants in derogation of sovereignty are narrowly construed to preserve sovereign autonomy, see, e.g., William N. Eskridge, JR. \& Philip P. Frickey, Cases and Materials on Legisla. tion: Statutes and the Creation of Public Policy 653 (2d ed. 1995), the oil companies, not the tribe, should have been expected to raise the issue of taxation authority and to negotiate about it. See Merrion, 455 U.S. at 147-48 (adopting the view that even a sovereign holding a royalty interest under a contract retains taxation authority concerning it unless that authority was "surrendered in unmistakable terms"). In contrast, in Montana, there was no way that the non-Indian fee owners could have negotiated regarding potential tribal civil jurisdiction because Congress had unilaterally imposed the land-ownership scheme many years before.

128 As Gould recognized, at the outset of the period of his study the Supreme Court had remarked that tribes "are unique aggregations possessing attributes of sovereignty over both their members and their territory," Gould, supra note I5, at 839 (quoting United States v. Mazurie, 4I9 U.S. 544, 557 (1975) (citing Worcester v. Georgia, 31 U.S. (6 Pet.) 515, 557 (1832))) (internal quotation marks omitted), and thus "are a good deal more than 'private, voluntary organizations." Id. at 839 (quoting Mazurie, $4 \mathrm{Ig}$ U.S. at 557 (quoting United States v. Mazurie, 487 F.2d 14, 19 (10th Cir. I973))) (internal quotation marks omitted). What the cases that Gould surveyed, see id. at 837-54, demonstrate is that, over the last two decades, the Court has waffled on whether to continue to recognize the distinction between governmental authority rooted in sovereignty and associational authority based on consent.

129 See Frickey, supra note 4, at 1203 . I am referring here to the law on the books, not to the interactions between tribes and non-Indian entities that have defined much of the broad, practical parameters of the colonization of this country. 
Indian law ${ }^{130}$ than does Gould's unidimensional model or Benjamin's flattening of the field into general federal public law.

Many legal scholars would respond to the incoherence in this field by proposing theoretical modifications and doctrinal reforms to bring a more normatively attractive and descriptively coherent approach to it. 131 Yet the question whether such scholarly reforms of the field are likely to be successful, and the even more basic question of what constitutes meaningful reform in the first place, are inquiries that are daunting in themselves and deserve attention. Indeed, as the next Part suggests, a more satisfactory approach might prefer local answers that are developed through negotiated conciliation to analytically elegant global solutions that may be unattainable or impractical.

\section{The Curbing of Conceptualization and the Promise of Participation - OR, Decolonization FROM THE INSIDE OUT}

One obvious problem with theoretical reconceptualizations of federal Indian law that have practical impact as a goal is that they must appeal to the legal elite 132 - which is, of course, non-Indian. For example, Robert A. Williams, Jr., has demonstrated that indigenous practices and values have influenced federal Indian law and, under a broader conception of the field, should influence it more substantially in the future. ${ }^{133}$ But how can any transformation of the field occur when judges, cabined by the blinders of precedent, will dismiss such indigenous aspects as irrelevant, and when (largely non-Indian) scholars, though often sympathetic, will have difficulty identifying the Indian side of the story, much less integrating it into conceptual arguments for reform of the field? Scholars may exhort judges to hear the other side of the story, but may know too little about that side themselves, and thus may offer only abstract (and ultimately hollow) exhortations to think about things from the Indian perspective. ${ }^{134}$

To the extent that scholarly efforts in federal Indian law presume, if only implicitly, that federal judges could accomplish a decolonization of federal Indian law if only they would see the light, the scholarly activity is unlikely to be practically productive. Although I am

130 See generally $i d$. at II 74-I203 (discussing the tension between uniqueness and uniformity in federal Indian law).

131 My own efforts in this regard are cited above in note 81.

132 Cf. Henry Paul Monaghan, Stare Decisis and Constitutional Adjudication, 88 Colum. L. REv. 723,749 (1988) (noting that the legitimation of law may be an elite endeavor).

133 See Robert A. Williams, Jr., "The People of the States Where They Are Found Are Often Their Deadliest Enemies": The Indian Side of the Story of Indian Rights and Federalism, 38 ARIz. L. REv. 98I, 987-97 (I996).

134 See, e.g., Frickey, supra note 4, at $1219-22$ (noting that appeals to the Indian side of a case may sound quaint and hollow); Gerald Torres \& Kathryn Milun, Translating Yonnondio by Precedent and Evidence: The Mashpee Indian Case, I9go DuKE L.J. 625, 628-30 (discussing the diffculty of translating an Indian context into legal practice). 
not entirely pessimistic about doctrinal innovation and do believe that scholarly inquiry assessing judge-made federal Indian law is a worthy task, candor compels me to admit that it is unlikely to produce any truly wide-ranging reform of this field. I do not say this simply because the trend in the cases is unfavorable to Indian tribal claims. ${ }^{135}$ The more fundamental problem is that the doctrines in the field are rooted in such strong colonial assumptions ${ }^{136}$ that innovation can go only so far in attempting to promote a more respectful treatment of tribes. In addition, the indigenous perspective has been injected into this law in, at best, only a roundabout and filtered way, through the work of (usually non-Indian) attorneys representing tribes and (almost always non-Indian) scholars who attempt to provide meaningful critiques of the field that are more sensitive to tribal interests. ${ }^{137}$

The short answer to the question of reform, then, is that, in these fundamental ways, the field is structurally immunized against substantial doctrinal reevaluation. Litigation may rearrange the rafters of this law, but is very unlikely to shake its foundations. Scholarship which rarely drives law reform anyway - is even more likely to have a quixotic quality here. Moreover, the highest academic aspirations of scholarship - to examine a question from all sides with a genuine quality of objectivity and disinterestedness - face at least a twofold problem in this field. First, to the extent that even scholarship of this kind is rather uniformly highly critical of the field, it becomes easier for more practically minded opponents of reform to dismiss it as mere practitioner advocacy masquerading as something more highfalutin. Second, a thorough scholarly examination of a problem of this social, cultural, historical, and doctrinal magnitude is fraught with difficulty, especially when the scholarly community lacks many members who can more naturally access and bring to the fore the Indian side of many of these facets. Although I certainly do not believe that this disqualifies non-Indians from undertaking scholarly work in the field, it does suggest a certain humility and tentativeness to their efforts, which in turn may appear to the opponents of reform not just as a lack of confidence in conclusions that they have drawn, but as partiality or pandering as well.

One central, albeit controversial, value shared by many academic lawyers is a faith in properly designed institutional organization and procedure. ${ }^{138}$ If federal Indian law is currently structured in a way

135 See Robert N. Clinton, Peyote and Judicial Political Activism: Neo-Colonialism and the Supreme Court's New Indian Law Agenda, 38 FED. B. NEws \& J. 92, 92-93 (I99I).

136 See Robert A. Williams, Jr., The American Indian in Western legal Thought 325-28 (1990).

137 See, e.g., Williams, supra note $\mathrm{I} 33$, at $98 \mathrm{I}-87$.

138 See Henry M. Hart, Jr. \& Albert M. Sacks, The Legal Process: Basic Problems IN the Making and Application of Law 3-4 (William N. Eskridge, Jr. \& Philip P. Frickey eds., I994). 
that is highly resistant to a thoroughgoing critique and reevaluation, might not there be ways to promote a more normatively defensible approach to the field not simply by proposing doctrinal innovation, but also by suggesting a structural or procedural redesign of the ways in which this law is made? By engaging in ordinary scholarly normative and doctrinal analysis of the field, perhaps we have placed the cart before the horse. Indeed, if there really is a paradigm in federal Indian law that should be shifted, it might well be one based not on consent, but on adjudication.

Faith in adjudication is rooted deeply in the analytical instincts of many legal commentators, who might feel lost amid a shifting landscape if they no longer viewed their primary audience as the judiciary and their fellow scholars, with whom they operate in a joint enterprise of improving the law incrementally. As the examination of Benjamin's and Gould's contributions has demonstrated, however, the adjudicatory model has never worked very well in federal Indian law and, in recent years, has increasingly failed to promote the interests of $\mathrm{Na}$ tive Americans and their tribes.

Moreover, it is the adjudicatory model of defining federal Indian law that leads to the fixation on where the Supreme Court "is" on any given issue at the moment or, more broadly, on whether a consistent trend is emerging. To be sure, I believe that both inquiries are well within the appropriate analytical domain. But overemphasis on the doctrinal aspects of current federal Indian law, measured from this day backward, obscures both the extent to which the field remains incoherent and the extent to which the "answers" to particular issues are mere constructs that are rooted in fiction rather than plausible precedent, not to mention the degree to which the entire field is inextricably rooted in colonial notions that are simply inconsistent with any plausible contemporary normative universe.

So deeply rooted is the faith in adjudication that it may be difficult for many members of the American legal community to imagine any meaningful alternative. Yet, both within Native American communities and in their relationships with European nations and the United States, there has been a rich tradition of sharing values through dialogue and negotiation. ${ }^{139}$ The notion that tribes are inextricably linked to the United States government and its people may be a plausible conclusion of law based on precedent, ${ }^{140}$ but it is much more clearly

139 See, e.g., Robert A. Williams, Jr., Linking Arms Together: Multicultural Constitutionalism in a North American Indigenous Vision of Law and Peace, 82 CAL. L. REv. 98I, 983-84 (1994).

140 See Frickey, Marshalling Past and Present, supra note 8r, at 406-r7 (suggesting that Indian treaties are constitutive documents linking tribes and the federal government); Williams, supra note 133 , at $99 \mathrm{I}-92$ (emphasizing the concept of treaty as a sacred, interlinking text).

One of the most interesting federal-tribal linkages in current law occurs when, pursuant to the Supreme Court decisions discussed above at $p$. 1773, litigants must exhaust their tribal-court remedies before seeking federal judicial relief. This approach gives tribal courts the front-line respon- 
proved, as a conclusion of life, by assessing the intertwined histories and practices of Natives and Euro-Americans. The potential contemporary significance of this insight would be hard to overstate. ${ }^{141}$

Imagine, for example, that the federal government and a tribe viewed each other as sovereigns linked in an ongoing - indeed, perhaps perpetual - relationship of governance. Imagine further that a controversy arises concerning whether a federal regulatory scheme for example, the Endangered Species Act - applies on the tribal reservation and, if so, how its mandates are to be implemented. To be sure, litigation in federal court could "resolve" the matter, but only in a thin and unsatisfying sense. Among the many problems that could result, consider two: first, a federal victory may never be accepted by the tribe, which may well consider itself sovereign within its reservation borders and deeply resent the invasion of federal officials, even for purposes that are arguably laudable in the abstract; second, a tribal victory might produce an unnecessary appearance of inconsistency between environmental values and tribal autonomy, as well as eventual congressional efforts to undercut tribal sovereignty. Now imagine that, instead of litigating the issue, tribal and federal authorities approach the problem as simply one of many important matters for conversation between sovereigns which should be resolved by negotiation in good faith, and with an eye toward accommodating the federal and tribal interests not only on this question, but in a manner that

sibility for these disputes and provides venue for difficult questions of tribal law in the forum most competent to evaluate them. An illuminating illustration is United States $v$. Tsosie, $849 \mathrm{~F}$. Supp. 768 (D.N.M. r994), affd, 92 F.3d I037 (roth Cir. 1996), in which even the United States itself was required to exhaust tribal-court remedies. The United States had brought a trespass and ejectment action on behalf of itself and one Indian against another Indian concerning an Indian allotment. Based on a sworn declaration concerning tribal law given by the former chief justice of the tribe, the federal district court concluded that tribal common law, as well as federal law, might be relevant in the matter. See id. at 774-75. The federal judge continued:

As a non-Navajo, unschooled in the foundations of Navajo culture which, according to

Justice Tso, constitute Navajo common law, I am unqualified to interpret the law and rule on many of the legal issues which should arise in this case. As noted in [Supreme Court precedent], tribal courts are best qualified to interpret and apply tribal law.

Id. at 775 (citation omitted).

141 Indeed, recent federal Indian law scholarship contains some consideration of the potential advantages of negotiation and settlement over adjudication. See POMMERSHEIM, supra note $\mathrm{I}_{3}$, at 153-56, 158-6r; Clinton, supra note 3, at 158-59; P.S. Deloria \& Robert Laurence, Negotiating Tribal-State Full Faith and Credit Agreements: The Topology of the Negotiation and the Merits of the Question, 28 GA. L. REv. 365, 373-74 (1994); Vine Deloria, Jr., Laws Founded in Justice and Humanity: Reflections on the Content and Character of Federal Indian Law, 31 ARIz. L. REV. 203, 218 (1989); Gould, supra note 15, at 901-02; Kevin Gover \& James B. Cooney, Cooperation Between Tribes and States in Protecting the Environment, NAT. Resources \& ENV'T, Winter 1996, at 35; Gover, Stetson \& Williams, P.C., Tribal-State Dispute Resolution: Recent Attempts, 36 S.D. L. REv. 277, 277-98 (1991); Janet C. Neuman, Run, River, Run: Mediation of a Water-Rights Dispute Keeps Fish and Farmers Happy - for a Time, 67 U. CoLO. L. REV. 259, 261 (1996); Charles F. Wilkinson, To Feel the Summer in the Spring: The Treaty Fishing Rights of the Wisconsin Chippewa, 1991 WIS. L. REv. 375, 404; Gina McGovern, Note, Settlement and Adjudication: Resolving Indian Reserved Rights, 36 ARIz. L. REV. I95, I95-222 (1994). 
strengthens the long-term relationship as well. This more productive tack was recently taken by the White Mountain Apache Tribe and the United States Fish and Wildlife Service, which negotiated an arrangement under which the Tribe would manage the protection of sensitive species in cooperation with the Service. ${ }^{142}$

Of course, it would be foolish to generalize from only one example and conclude that alternative dispute resolution is the cure for all that ails federal Indian law. If the problem is that adjudicatory federal Indian law too often is law without life, the correlative problem is that negotiated federal Indian law may threaten to become life without law. There may be a rich tradition of fruitful negotiation and exchange, but might that not be more an artifact of history than a potential contemporary reality? Tribes no longer possess the historical advantages of comparative numerical, geographic, and military strength. What is to prevent federal and state negotiators from attempting to run roughshod over the interests of tribes? Might not the White Mountain Apache Tribe agreement likely be the exception and not the rule?143

A simple answer is that tribes are unlikely to roll over and play dead. Institutions that have survived a half-millennium of colonization have shown a profound resilience in the face of overwhelming odds. It seems virtually impossible, as well as paternalistic, to believe that tribes might voluntarily negotiate away their central interests. If those are to be lost, it will be by unilateral exercises of colonial power which federal Indian law doctrine still authorizes.

And there lies one of the essential paths for reform of this area of law. To be sure, there will always be adjudication in federal Indian law. Negotiation cannot completely displace other forms of dispute resolution, and scholars should continue to contribute to the dialogue that is immediately relevant to judicial assessment of federal Indian law. These are essentially trivial insights, however, for under a broader understanding of the role of law, federal Indian law provides the institutional and doctrinal structure around which negotiations oc-

142 See Statement of the Relationship Between the White Mountain Apache Tribe and the U.S. Fish and Wildlife Service (Dec. 6, x994) (copy on file with the Harvard Law Library). For later comments on this remarkable arrangement submitted by the tribal chairman to a Senate subcommittee, see Endangered Species Act Reauthorization: Hearings before the Subcomm. on Drinking Water, Fisheries, and Wildlife of the Senate Comm. on Environment and Public Works, ro4th Cong. 142-55 (1995) (including prepared statement of Ronnie Lupe, Chairman of the White Mountain Apache Tribe, and copy of the Statement of the Relationship). I am indebted to Joseph Kalt, who has served as a consultant to the tribe, and to Charles Stringer, my former student, who now serves as an attorney for the tribe, for independently bringing this arrangement to my attention.

143 One obvious factor is the receptivity of the federal executive branch to negotiations with tribes. The stated policy of the current administration is to promote conciliation within a framework conceptualized as a government-to-government relationship. See President's Memorandum for the Heads of Executive Departments and Agencies, 59 Fed. Reg. 2295 I (I994). 
cur. ${ }^{144}$ Some recent scholarship has focused on the possibility of reimagining federal Indian law in this way: not as a panglossian source for newly articulated tribal rights so much as a structure that establishes constraints to limit non-Indian exploitation of unequal negotiating power and provides breathing space for the flourishing of tribal institutions free from non-Indian intrusion. ${ }^{145}$ Moreover, scholars might propose imaginative alternatives even in the adjudicative arena, such that judges are not always faced with either-or choices about Native claims and can promote negotiated settlement of such claims within a framework that fosters respect for Native interests. ${ }^{146}$

To be sure, there are formidable challenges associated with attempting to bring about a greater degree of conciliation in federal Indian law. ${ }^{147}$ Moreover, it is not clear whether federal Indian law

144 Cf. Robert H. Mnookin \& Lewis Kornhauser, Bargaining in the Shadow of the Law: The Case of Divorce, 88 YALE L.J. 950, 950, 968-69, 997 (I979) (discussing the relationship between legal rules and settlement behavior).

145 See, e.g., Philip P. Frickey, Context and Legitimacy in Federal Indian Law, 94 MrCH. L. REv. 1973, I990-92 (1996) (reviewing PoMmerSheIM, supra note 13, and summarizing Pommersheim's vision of federal Indian law reform).

146 See, e.g., County of Oneida v. Oneida Indian Nation, 470 U.S. 226, 253 (I985) (holding that the tribe had a viable claim of unextinguished title to lands long ago lost to Euro-Americans, but assuming that Congress would ultimately settle the dispute).

147 This Commentary is hardly the place to begin a concentrated analysis of the problem. Perhaps it is enough to note two things. First, very able practitioners of federal Indian law have given me diametrically opposed comments on the general utility of alternative dispute resolution in the field. No doubt a great measure of the problem is that tribal relations exist with so many different entities (for example, with other tribes, the federal government, one or more states and their various political subdivisions, and non-Indian neighboring property owners) with which tribes have often been in historical discord and that themselves have many cross-cutting interests. The attempt to settle such "polycentric" disputes, to use Lon Fuller's term, see Lon L. Fuller, The Forms and Limits of Adjudication, 92 HARV. L. REV. 353, 394 (1978), can be a daunting task. For example, the Oneida land claims dispute in New York, referred to in note 146 above, remains unsettled, at least in part because of the conflicting interests of the three Oneida bands involved, which are located in New York, Wisconsin, and Canada. See, e.g., Land Claim Talks Urged: Further Litigation May Be Needed If a Settlement Isn't Reached in the Oneida Indians' Claim, A Federal Official Warns, Syracuse Herald-Journal, Dec. 12, 1996, at Br. After a settlement concerning the extent of off-reservation hunting and fishing rights negotiated between the State of Minnesota and the Mille Lacs Band of Chippewa Indians fell through when the state legislature, under intense pressure from non-Indian hunters and fishers, refused to appropriate the money necessary to fund it, the tribe obtained judicial relief far in excess of what it had been willing to accept under the settlement. See Mille Lacs Band of Chippewa Indians v. Minnesota, 952 F. Supp. 1362 (D. Minn. 1997); Mille Lacs Band of Chippewa Indians v. Minnesota, 861 F. Supp. 784 (D. Minn. 1994); Editorial, Tribal Wrongs: Disastrous Lawsuit Continues Apace, MinNeAPoLrS STAR TruB., Feb. 8, 1997, at 22A; Judge Backs Tribal Fishing Claims: Ruling Allows Chippewa to Exert Treaty Rights, MinNEAPOLIS STAR TrIB., Jan. 30, 1997, at IB.

Second, even a peek into the burgeoning literature on negotiation suggests that federal Indian law disputes often involve significant barriers to settlement in addition to the problems of polycentricity and historical discord that may lead to intransigence. For instance, in a helpful overview on conflict resolution, Robert Mnookin and Lee Ross discuss certain psychological factors that are commonly posited as barriers to settlement. See Robert H. Mnookin \& Lee Ross, Introduction, in BARRIERS To CoNflict Resolution 3, IO-I9 (Kenneth J. Arrow, Robert H. Mnookin, Lee Ross, Amos Tversky \& Robert B. Wilson eds., I995). These problems - insisting 
scholars, who are accustomed to doctrinal and reformist analysis, could contribute effectively to a broader approach to dispute resolution in this field. At least some of us might need to retool and become more familiar with, for example, the literature on resolving disputes between entities in long-term relationships ${ }^{148}$ and less fixated on the most recent footnote in a Supreme Court opinion. Indeed, at least when phrased in this way, the shift in focus sounds attractive even in the narrow, instrumental sense.

In the last analysis, negotiation seems to promise to bring Indians into Indian law far better than does adjudication. Negotiation turns not on incoherent or misunderstood legal doctrines, but on practical realities. Negotiation gives people - including subordinated people a piece of the legal action and a chance to own, if only partially, both the resolution of particular disputes ${ }^{149}$ and a greater sense of the structure and efficacy of the long-term relationships between the parties. ${ }^{150}$ It goes without saying - although it may nonetheless need to be said - that Indians have not attained important federal judicial positions, and that few Indians are situated to contribute to the traditional scholarly dialogue. In contrast, every tribe has a sovereign structure of leadership and accountability that provides ready linkage to the process of negotiation. There would be no better way to hear the other side than to promote the design of institutions of direct dialogue and negotiation among tribal leaders and state and federal officials, rather than indirect adjudicative confrontation by lawyer-agents of these sovereignties. Indeed, it is no small irony that, although much federal Indian law doctrine is based on judicial deference to the perceived "ac-

on a "fair" or "just" settlement; a sense of entitlement based on a perception of past injustice; a tendency to inflate one's own concessions and to undervalue those offered by others; the skewing effects of risk aversion or overconfidence in one's position; and the difficulty of admitting that, in retrospect, one failed to take advantage of good opportunities to settle a long-term dispute - are likely to be especially acute in at least some federal Indian law conflicts, as anyone familiar with the off-reservation hunting and fishing controversy in Minnesota must acknowledge. Moreover, it goes without saying that negotiations in federal Indian law will be institutionally situated, raising all kinds of principal-agent difficulties, including the extent of authority delegated to negotiators, the quality of the information flowing from negotiators to their principals, and the difficulty of identifying and maintaining the stability of the principal itself in a context in which dissident tribal members may attempt to sway or to replace the tribal council, unhappy non-Indian landowners may motivate some state legislators to undercut the governor, and so on. For a brief overview of such institutional barriers to settlement, see id. at 19-22.

148 See, e.g., John T. Dunlop, The Creation of New Processes for Conflict Resolution in Labor Disputes, in BARRIERs to CoNFLICT RESOLUTION, supra note 147 , at 275, 275-90; Wolfgang Panofsky, Barriers to Negotiated Arms Control, in Barriers to Conflict Resolution, supra note 147, at 310, 311-29; Lawrence Susskind, Barriers to Effective Environmental Treaty-Making, in BARRJers to CONFLICT ReSOlution, supra note 147, at 292, 293-309.

149 See Deloria, supra note I4I, at 2 I8.

150 See Vine Deloria, Jr., Reserving to Themselves: Treaties and the Powers of Indian Tribes, 38 ARIz. L. REV. 963, 970-72, 979-80 (1996) (arguing that the historical treaty process should serve as the guideline for a new framework of tribal-federal, government-to-government negotiation). 
tual state of things, ${ }^{151}$ negotiation rather than adjudication is often a better vehicle for defining and shaping current reality, not to mention a more productive way for the state of things perceived by subordinated peoples to be made relevant and credited with legitimacy.

Of course, institution-building and alternative dispute resolution are not panaceas for federal Indian law. After a half-millennium of colonization, I am skeptical that anything approaching a "solution" in this area will ever emerge, whether by doctrinal innovation or its alternatives. But in a field with too much law and too little life, it might be time for scholars to focus at least as much on questions of legal process as on matters of legal doctrine. From that perspective, not only should we articulate more clearly the objectives of federal Indian law, but we should also give greater attention to the manner in which institutions of law carry out their responsibility of "establishing, maintaining and perfecting the conditions necessary for community life to perform its role in the complete development of [people]."152 $\mathrm{Be}$ cause our broader, contemporary community could not have come about without the unilateral displacement of indigenous communities, it seems especially the case that the institutions and processes of the nation should foster the capacity of Natives to govern their own communities as well as contribute to the development of all our peoples, indigenous or immigrant.

151 In both Worcester v. Georgia, 3 I U.S. (6 Pet) 515 (1832), and Johnson v. McIntosh, 2I U.S. (8 Wheat.) 543 (1823), Chief Justice Marshall suggested that the doctrines of federal Indian law must reflect "the actual state of things." Worcester, 3 I U.S. (6 Pet) at 543, 546, 560; Johnson, 2I U.S. (8 Wheat) at 590-9I.

152 HART \& SACKS, supra note 138 , at 102 (quoting Joseph M. Snee, Leviathan at the Bar of Justice, in GoverNmENT UNDER LAW 91, 96 (Arthur E. Sutherland ed., 1968)) (internal quotation marks omitted). 